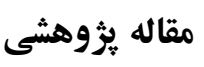

مجله دانشگَاه علوم يزشكى رفسنجان

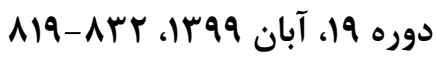

مقايسه تأثير شاكى ويو درمانى و ليزر كم توان در درمان نقاط ماشهاى ميوفاسيال عضلات

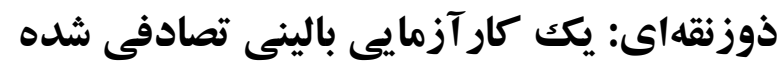

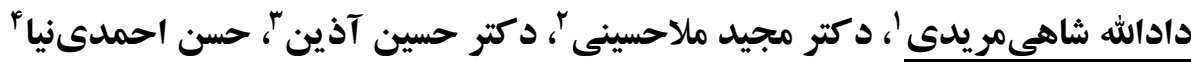

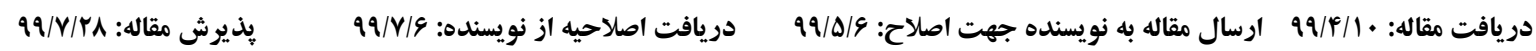

زمينه و هدف: عضلات يكى از علل ايجاد كننده درد در بدن انسان مىباشند. در بين انواع دردهاى عضلانى، نقاط ماشهاى

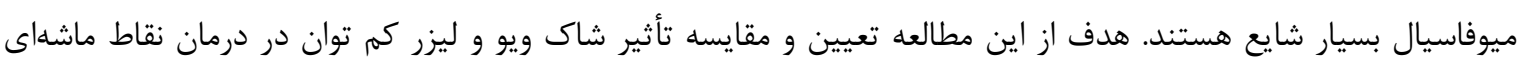
ميوفاسيال عضلات ذوزنقهاى بود.

مواد و روشها: اين مطالعه كارآزمايى بالينى تصادفى شده، در كلينيك فيزيوترايى فاطميه(س) رفسنجان در سال 19

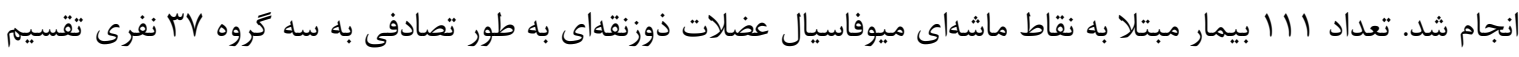
كرديدند. بيماران، روشهاى درمانى شامل شاك ويو، ليزر كم توان و درمان رايج فيزيوترايى را به مدت لـ ل1 جلسه دريافت

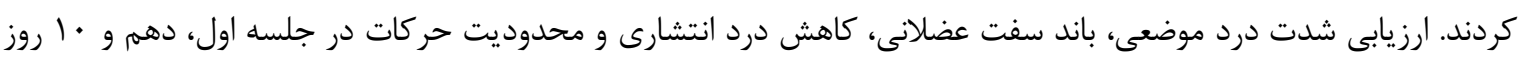

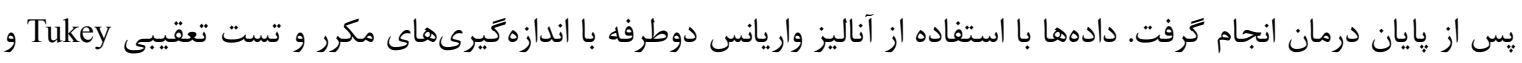
آزمون مجذور كاى تجزيه و تحليل شدند.

يافتهها: نتايج اين مطالعه نشان داد شاك ويو در طى • إ جلسه در كاهش شدت درد موضعى نقاط ماشهاى ميوفاسيال مؤثرتر

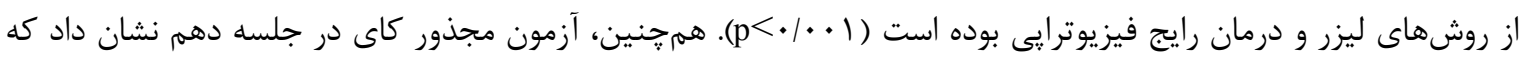

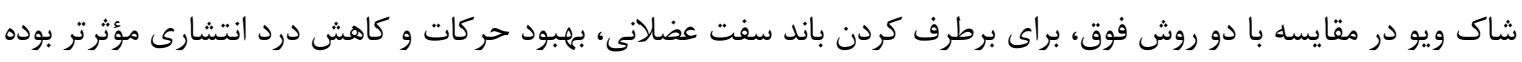
است ( ) ( )

نتيجهَيرى: از يافتهاى اين مطالعه مىتوان نتيجه كرفت كه شاك ويو در طى • ا جلسه مىتواند در كاهش شدت درد موضعى، درد انتشارى، بهبودى حركات و برطرف نمودن باند سفت عضلانى مؤثر باشد.

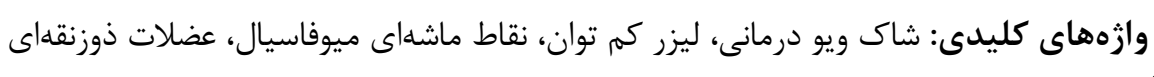

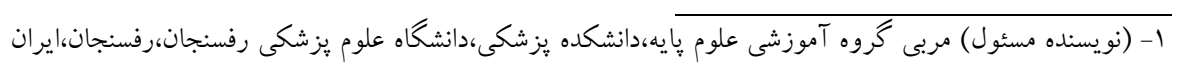

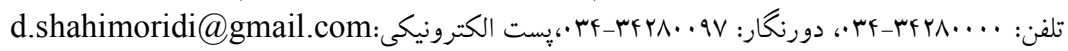

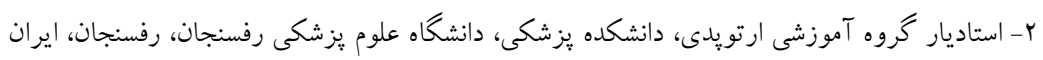

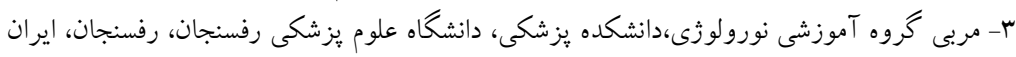

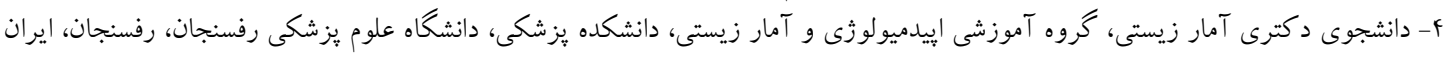


• . م مقايسه تأثير شاك ويو درمانى و ليزر كم توان در درمان نقاط ماشهاى ميوفاسيال ...

نقاط ماشهاى ميوفاسيال منفى هستند و فقط از طريق

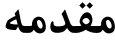

معاينات فيزيكى مخصوص تشخيص داده مىشود [9 [1 19]. آنجه در درمان نقاط ماشهاى ميوفاسيال اهميت دارد اين است كه زود تشخيص داده شوند تا درمانهاى مناسب انجام

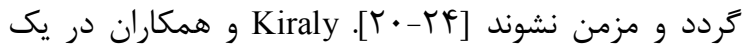
تحقيق اع بيمار را در دو گروه شاك ويو (Shockwave) و ليزر به مدت ها جلسه تحت درمان قرار داد. آنها دريافتند كه هر دو روش در درمان نقاط ماشهاى ميوفاسيال عضله ذوزنقهاى مؤثر هستند ولى در مقايسه شاك ويو از ليزر در كاهش شدت درد موضعى، درد انتشارى، از بين بردن باند سفت عضلانى و بهبودى حركات مؤثرتر بوده است [Khalil د در يك مقاله تحقيقى دريافت كه اولتراسوند و شاك ويو هر دو در كاهش درد و افزايش عملكرد و حركات كردن در مبتلايان به نقاط ماشهاى ميوفاسيال عضله ذوزنقاى مؤثر هستند ولى در مقايسه شاك ويو از اولتراسوند مؤثرتر، ايمن، ارزان و كاربرد بهترى دارد [هـ]. درمانهاى دارويى نقش تسكينى دارند و علت اوليه درد را برطرف نمى كنند در حالى كه روشهاى فيزيوترايى نظير كشش عضله، اولتراسوند، ماساز ايسكميك و اخيراً شاك ويو و ليزر كم توان در درمان اين كونه دردها استفاده مىشود و اثر خوبى هم داشته است [Y [V-D، Y T-19]. تحقيقات در زمينه كاربرد شاك ويو در درمان نقاط ماشهاى نشان مىدهد كه اين روش مىتواند سبب ترميم، بازسازى بافتهاى عضلانى، سبب غير فعال شدن و از بين رفتن باند سفت عضلانى مىشود. قابل ذكر است امواج شاك ويو مانند امواج اولتراسوند هستند كه در خارج از بدن

عضلات به عنوان يك عامل ديناميك نقش اصلى را در فعاليتهاى روزمره زندكى انسان بر عهده دارند. بافت عضلانى بيشتر از ساختارهاى ديكر بدن در معرض پاركى هاى كوجى و فرسايش در طول فعاليتهاى روزانه قرار كرفته و سبب درد مىشوند. در حالى كه يزشكان و درمانَران در هنكام معاينه بيمار از لحاظ تفسير درد به استخوانها، مفاصل، اعصاب مركزى و محيطى توجه بيشترى دارند [r-1]]. مطالعاتى كه در زمينه إِيدميولوزى دردهاى عضلانى انجام شده، نشان مى دهد كه نقاط ماشهاى ميوفاسيال فوق العاده شايع هستند. به طورى كه فه درصد دردهاى كردن و لم درصد دردهاى كمر و يشت ناشى از نقاط ماشهاى ميوفاسيال مىباشند [ه1]. نقطه ماشهاى (Myofascial trigger point) به عنوان يك نقطه بسيار حساس نسبت به تحريك تعريف مىشود كه در باند سفتى از عضله اسكلتى و يا در فاسياى آن قرار دارد اين نقطه با فشار دردناك شده و درد انتشارى ايجاد مىنمايد [؟9]. به طور كلى مىتوان كفت اين باندها به دنبال بار اضافى و و استفاده زياد (Overload) طورى كه عضله قادر به پاسخ كويى كافى نباشد سبب آسيب فيبرهاى عضله شده و انقباض آن مىشود كه مواد سمىنظير برادى كينين، يروستاكَاندين، هيستامين، يتاسيم در آن ناحيه تجمع مىيابند كه سبب تشكيل باند سفت مى كردد [ [ا - • ا]. تستهاى آزمايشًاهى، راديوگرافى، سىتىاسكن و. جهت تشخيص (MRI) Magnetic Resonance Imaging 


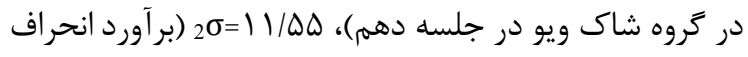
معيار شدت درد موضعى در گروه ليزر درمانى در جلسه دهم)، k=1 (حجم نمونه در زروهها به تعداد مساوى تعيين گرديد)، • • گروههاى مورد بررسى كه از نظر بالينى حائز اهميت در نظر گرفته شد) و بنابراين حجم نمونه در هر گروه V نفر و در

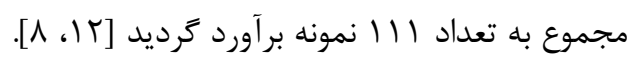
بيماران برحسب مراجعه و بلصورت در دسترس انتخاب و به شيوه بلوكهاى جايگشتى تصادفى با اندازه س، براى تخصيص بيماران به گروههاى شاك ويو درمانى، ليزر كم توان و فيزيوترايى رايج تقسيم تصادفى شدند و در سه گروه تحت درمان يكى از روشهاى مطالعه به صورت يك روز درمان به مدت · ا جلسه قرار زرفتند (شكل (). روش تصادفى سازى به اين صورت بود كه فرد ارزياب در ابتداى ورود، بيماران را بررسى مىكرد و در صورت داشتن شرايط مطالعه، از روى جدول اعداد تصادفى، بيماران را بررسى مىكرد و در صورت داشتن شرايط مطالعه، از روى جدول تصادفى، بيماران را به سه گروه تقسيم و به درمانگر ارجاع مىداد. همرجنين در جلسات اول، دهم و يك ماه يس از پايان درمان، آنها را ارزيابى مىنمود. مشخصات دموكرافيك مانند سن، جنس، شغل، شدت درد موضعى، درد انتشارى، باند سفت و كاهش دامنه حركات در جّ ليست ثبت گرديد. بيماران در ابتداى ورود، فرم رضايت نامه تكميل نمودند و در جريان مطالعه قرار مى گرفتند. تمامى بيماران شركت كننده در اين تحقيق به طور رايگان درمان شدند. همرجنين كد اخلاقى از
توليد شده و با ضربه به داخل بدن وارد مىشود [צץ-با1]. هم جنين ليزر مىتواند باعث ترميم بافت نرم،كاهش دردهاى عضلانى، اسكلتى، افزايش جريان و كاهش التهاب شود [FF_ צr، ז (1، ه]. از ميان درمانهاى فيزيوترايى به نظر مىرسد همين دو مورد يعنى شاك ويو و ليزر كم توان در درمان نقاط ماشهاى ميوفاسيال بيشتر مطرح هستند و برخلاف داروها ضررى هم ندارند. ولى از آنجايى كه آثار درمانى دو روش فوق بر روى اين بيمارى كاملاً مشخص نيست و گزارشهاى ضدو

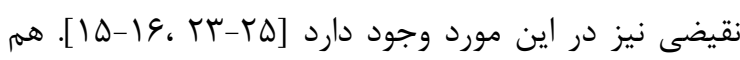
جنين در اين زمينه مقايسهاى بين دو روش مذكور انجام نشده است. از طرف ديگر اين دو روش جديد مىباشند و با توجه به مكانيسم اثر آنها احتمالاً در درمان نقاط ماشهاى ميوفاسيال مفيد باشند بنابراين هدف ما در اين مطالعه مقايسه تأثير شاى ويو درمانى و ليزر كم توان در درمان نقاط ماشهاى ميوفاسيال عضلات ذوزنقهاى بود.

\section{مواد و روشها}

اين مطالعه به صورت كارآزمايى بالينى تصادفى شده از

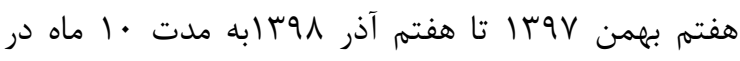
درمانگاه فيزيوترايى فاطميه (س) رفسنجان انجام كرفت. جامعه يروهش شامل كليه بيماران مبتلا به نقاط ماشهاى ميوفاسيال عضلات ذوزنقهاى بودند كه در زمان فوقالذكر به كلينيك فيزيوترايى مراجعه نمودند. با استفاده از فرمول $\alpha=\cdot / \Delta ه \times n_{1}, g^{n_{1}=\frac{\left(Z_{1-\frac{\alpha}{2}}+Z_{1-\beta}\right)^{2} \times\left(\sigma_{1}^{2}+\frac{\sigma_{2}^{2}}{k}\right)}{\Delta^{2}}}$

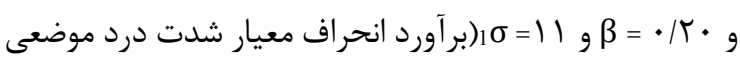


Tr مقايسه تأثير شاك ويو درمانى و ليزر كم توان در درمان نقاط ماشهاى ميوفاسيال ...

مذكور كار آزمايى بالينى ايران (www.irct.ir) به شماره IRCT20100129003220N10
كميته اخلاق دانشعاه علوم يزشكى رفسنجان به شماره IR.RUMS.REC.1397.239 اخذ شد. علاوه بر اين مطالعه

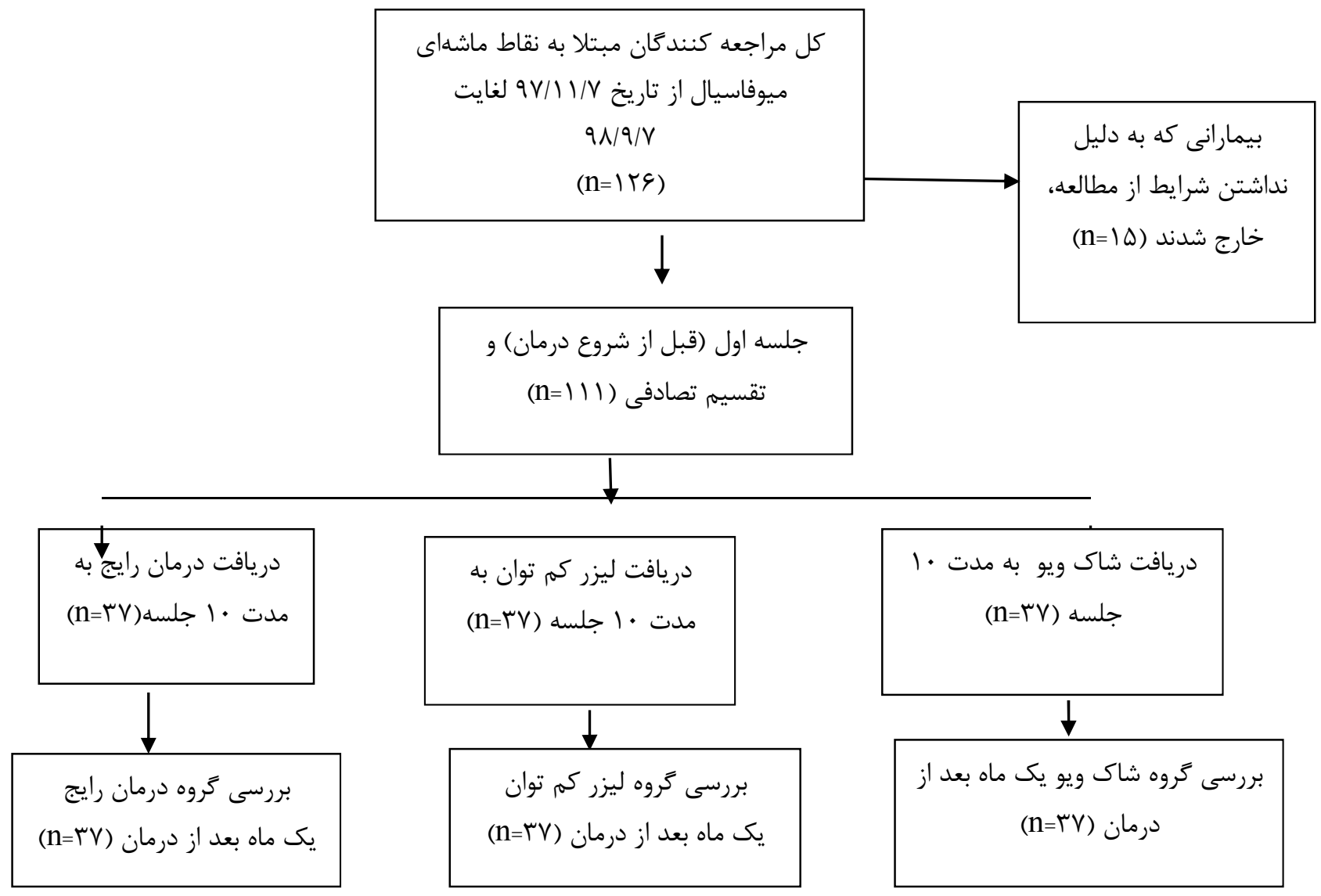

شكل ا - فلوجارت طراحى مطالعه اثرات شاكى ويو، ليزر كم توان و دومان رايج در درمان نقاط ماشهاي ميوفاسيال

تشخيص قطعى نقاط ماشهاى بايد ه معيار بزرى وحداقل يك معيار از r معيار كوجى وجود داشته باشد. معيارهاى بزرى عبارتند از: درد موضعى، درد انتشارى كه از نقطه ماشهاى منشأ مى گيرد، وجود باند سفت عضلانى و قابل لمس در عضلات گرفتار، حساسيت مشخص و دقيق در طول بافت سفت عضلانى و كاهش دامنه حركتى مفصل. معيارهاى كوجى شامل ياسخ انقباض عضلانى سريع، تغيير خود به خود حس درد بافشار بر روى نقاط ماشهاى، كاهش درد با كشش عضله
معيار انتخاب نمونهها بر اساس تشخيص متخصص ارتويدى استوار بود. يعنى بعد از آنكه بيماران معيارهاى ورود به مطالعه را داشتند به درمانگاه فيزيوترايى جهت انجام تحقيق ارجاع داده مىشدند. معيارهاى ورود به مطالعه شامل داشتن سن

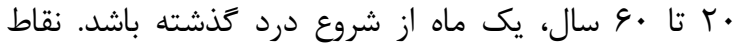
ماشهاى ميوفاسيال فقط در عضلات ذوزنقهاى وجود داشته باشد. همرجنين معيار انتخاب نمونهها بر اساس يافتههاى فيزيكى Travel و Simons استوار بود كه تأكيد دارند براى 
از مقياس آنالوى بصرى (Visual Analogue Scale ,VAS) استفاده شد كه انتهاى سمت جِ ٍ آن نقطه بدون درد و انتهاى سمت راست آن، درد بسيار زياد را نشان مىداد. براى اين كار از بيمار خواسته مىشد تا شدت درد خود را در جلسه اول (قبل از شروع درمان) جلسه دهم و يك ماه يس از پايان درمان بر روى خط مذكور علامت بزند [ ·r، 11]. دادهها يس از جمع آورى با استفاده از نرم افزار SPSS نسخه • ب مورد تجزيه و تحليل قرار گرفتند. نتايج براى دادههاى كمى به صورت انحراف معيار 土 ميانكين و براى دادههاى كيفى به صورت تعداد (درصد) گزارش گرديد. به منظور مقايسه ميانگين شدت درد موضعى در گروههاى مورد بررسى از آناليز واريانس يكطرفه و دو طرفه با اندازهيرىهاى مكرر Two-way) به همراه آزمون مقايسات repeated measures ANOVA) جند گ Tukey استفاده شد. به منظور مقايسه متغيرهاى كيفى از آزمون مجذور كاى استفاده گرديد. سطح معنىدارى در آزمونها ه • • در نظر كرفته شد.

نتايج بر اساس جدول ا، با استفاده از آزمون آمارى آناليز واريانس يك طرفه و مجذور كاى، بيماران از لحاظ سن، جنس، و شغل با هم تقريباً همسان و اختلاف بين متغيرها در سه گروه از نظر آمارى معنىىار نبود (ه •|• (p).

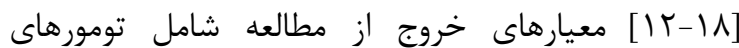
استخوانى و بافت نرم ناحيه گردن و يشت، مصرف داروهاى ضد انعقاد، نارسايى شديد كليه، تشنج، درد انتشارى ناشى از فشار روى اعصاب محيطى گردنى، مصرف داروهاى استروئيدى، سابقه جراحى و شكستگى گردن و يشت، حاملگى

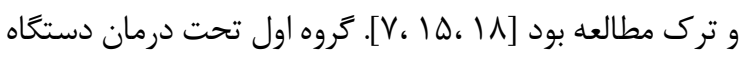
شاى ويو (ساخت شركت نوين ايران، مدل 360G)، با جگالى انرزى ^ صدم ميلىزول بر ميلىمتر مربع، فشار ه/ إبار، •1 فر كانس، · • لها ضربه (Shock) و به مدت ץ دقيقه روى هر

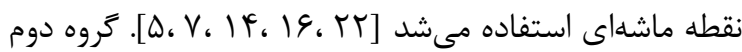
تحت درمان ليزر كم توان (كاليوم- آلومينيم- آرسنايد) ساخت شركت مترون استراليا با شدت ^ زول، توان • ا ميلى وات، طول موج • 1 1 نانومتر و به مدت ب دقيقه در هر نقطه ماشهاى استفاده مىشد [9 (19]. گروه سوم تحت درمان فيزيوترايى رايج شامل استفاده از دستخاه اولتراسوند (ساخت شركت ITO زإين) با فركانس ا مكاهرتز، شدت ه/ ا وات بر سانتىمتر مربع به مدت ه دقيقه روى هر نقطه ماشهاى استفاده مىشد. همجنين در اين روش عضله گرفتار به مدت ب دقيقه تحت كشش (Stretch) قرار داده مىشد [•r-9]. اثرات درمانى با اندازه كيرى شدت درد موضعى، بررسى فراوانى و درصد وجود و يا فقدان باند سفت عضلانى، درد انتشارى و محدوديت دامنه حركات گَردن بررسى گرديد. براى ارزيابى شدت درد موضعى

جلدول - مقا يسه توزيع فراوانى مشخصات فردى و ميانتين متغيرهاى تحت مطالعه در بلدو ورود در سه كروه درمانى بيماران مبتلا به نقاط ماشهاع ميوفاسيال

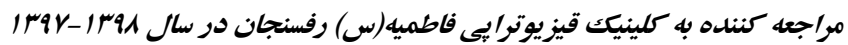

\begin{tabular}{|c|c|c|c|c|}
\hline مقدار P & $\begin{array}{r}\text { درمان رايج) } \\
(n=r \vee\end{array}$ & $\begin{array}{r}\text { ليز } \\
(\mathbf{n}=11)\end{array}$ & $\begin{array}{l}\text { شاك ويو } \\
(n=r V)\end{array}$ & روش هاى درمانى \\
\hline .1990 & $|f| / \Delta \mid \pm 11 / \lambda$ & $f / / \Delta q \pm \mid r / 1 q$ & $r I / r r \pm \mid r / \cdot r$ & سن (سال)" \\
\hline
\end{tabular}


FF مقايسه تأثير شاك ويو درمانى و ليزر كم توان در درمان نقاط ماشهاى ميوفاسيال ...

\begin{tabular}{|c|c|c|c|c|}
\hline \multirow[t]{3}{*}{ - /19१ } & & & & جنسيت \\
\hline & $(F+/ T) \backslash \varepsilon$ & $(f \cdot / \Delta) \mid Q$ & $(r V / \Lambda) \mid f$ & مرد \\
\hline & $(\Delta \& \mid \Lambda) \Gamma \mid$ & $(\Delta Q / \Delta) T r$ & (GT/T) & زن \\
\hline \multirow[t]{5}{*}{.$/ 99$} & & & & شغل \\
\hline & $(\mid r / \Delta) \Delta$ & $(19 / \pi)^{9}$ & $(19 / T)^{9}$ & كاركر \\
\hline & $(T V / T) r$ & $(\Lambda / 1) r$ & $(1 \cdot / \Lambda) F$ & كشاورز \\
\hline & $(Y Y / T) q$ & $(r q / V) 11$ & $(Y V) 1$. & خانه دار \\
\hline & $(Y \wedge / V) \backslash \wedge$ & $(\uparrow \varphi) I V$ & $(\uparrow \varphi) \backslash V$ & كارمند \\
\hline •/994 & $\Lambda r / q F \pm \Lambda / H Y$ & $\Lambda T / V T \pm \Lambda / r V$ & $\Lambda T / V \Lambda \pm \Lambda / \cdot \varphi$ & شدت درد موضعى" \\
\hline
\end{tabular}

\section{دادهها به صورت "تعلداد (درصد)" و يا "انحراف معيار 土 ميانتين" كزارش شلده است.

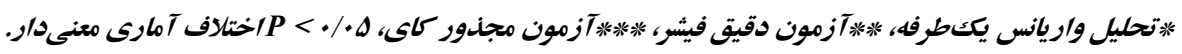

ميو فاسيال عضلات ذوزنقهاى نشان داد. براساس نتايج حاصل از آزمون مقايسات جندگانه زوجى Tukey روش شاك ويو به

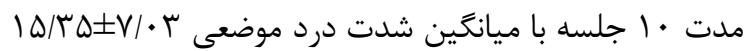
مؤثرتر از ليزر و درمان رايج در درمان درد موضعى نقاط ماشهاى عضلات ذوزنقهاى بود ( ( • | p) و ليزر بيشتر ازدرمان رايج بر روى درد موضعى نقاط ماشهاى اثر داشت ( Interactions) ( اثر متقابل) روشاى درمانى و

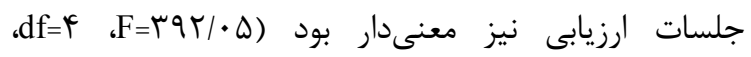
| • (p) به اين معنى كه الكوى كاهش شدت درد موضعى نقاط ماشهاى در طول دوره جلسات ارزيابى در روشهاى درمانى متفاوت بود. شيب كاهش شدت درد موضعى در روش شاك ويو به طور معنىدارى بيشتر از روشهاى ليزر و همرجنين شيب كاهش شدت درد در روش ليزر بيشتر از درمان رايج بود (جدول r).
همجٌين در جلسه اول شدت درد موضعى، باند سفت عضلانى، درد انتشارى، دامنه حر كات گردن در هر سه گروه از

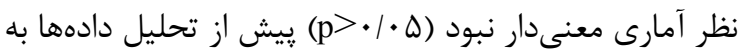
روش تحليل واريانس دوطرفه با اندازهگيرىهاى مكرر، پيش فرضهاى آن بررسى شد. نتايج آزمون Shapiro-Wilk نشان داد كه توزيع فراوانى متغيرهاى مورد بررسى در گروههاى مورد مطالعه پيش در مراحل يِيش آزمون و پِ آزمون از توزيع نرمال برخوردار است (ه •/p>). همرجنين آزمون ام باكس (Boxes M) و آزمون لون (Levene) نشان داد كه فرض

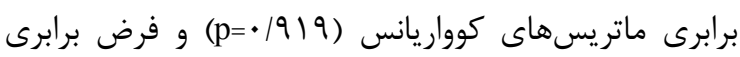
واريانس گروههاى مورد بررسى (ه) • (p) برقرار مىباشد. تحليل واريانس دو طرفه با اندازگيرىهاى مكرر ارتباط معنى

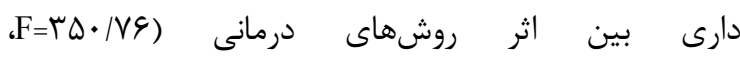

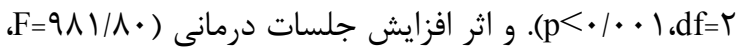

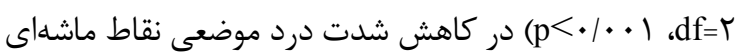




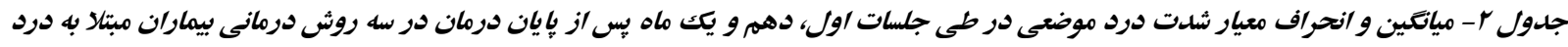

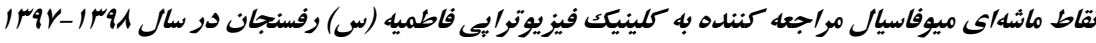

\begin{tabular}{|c|c|c|c|}
\hline يك ماه پيس از پيايان درمان & 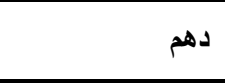 & اول & روشهاى درمانى ارزيابى \\
\hline $10 / \Gamma \wedge \pm 9 / 9$ & $1 \Delta / r V \pm V / \cdot r$ & $\Lambda r / \vee \Lambda \pm \wedge / \cdot 9$ & ش=rv شاك ويو \\
\hline$\Delta V / \wedge q \pm 11 / \%$ & $\Delta V / 9 V \pm 11 / 41$ & $\Lambda r / V \pm \Lambda / r^{q}$ & ليزر vr \\
\hline$\Lambda r / r q \pm \wedge / r \Delta$ & $\Lambda Y / r) \pm N / F$ & $\Lambda r / q r \pm \Lambda / r r$ & n=rv درمان رايج \\
\hline
\end{tabular}

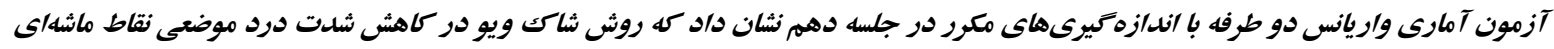

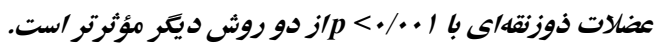
جلسه دهم مؤثرتر از ليزر و درمان رايج بوده است (FF/V9=F9 نتايج مطالعه حاضر نشان داد كه اختلاف معنى دارى از نظر

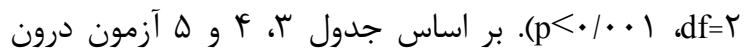
وجود يا فقدان باند سفت عضلانى در جلسه دهم بين روش گروهى كوكران (Cochran) نيز نشان داد كه هر سه روش شاك ويو، ليزر و درمان رايج وجود داشت به طورى كه درمان درمانى براى ار بين بردن باند سفت عضلانى، كاهش درد با شاك ويو /1/1 درصد موارد در مقايسه با روش ليزر و درمان انتشارى و بهبودى حركات در طى جلسات درمانى مؤثر بوده رايج براى از بين بردن باند سفت اثر بيشترى داشته است اند. اگر جه شاى ويو از ليزر و ليزر از درمان رايج اثر بهترى

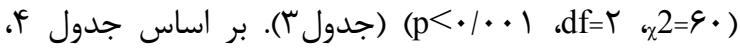
نشان داده است. شاى ويو در كاهش درد انتشارى در |ه/ د درصد موارد در

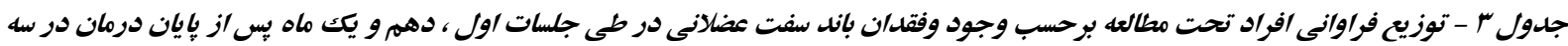

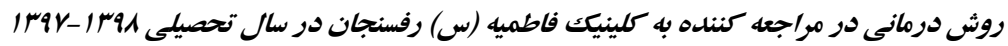


צr مقايسه تأثير شاك ويو درمانى و ليزر كم توان در درمان نقاط ماشهاى ميوفاسيال ...

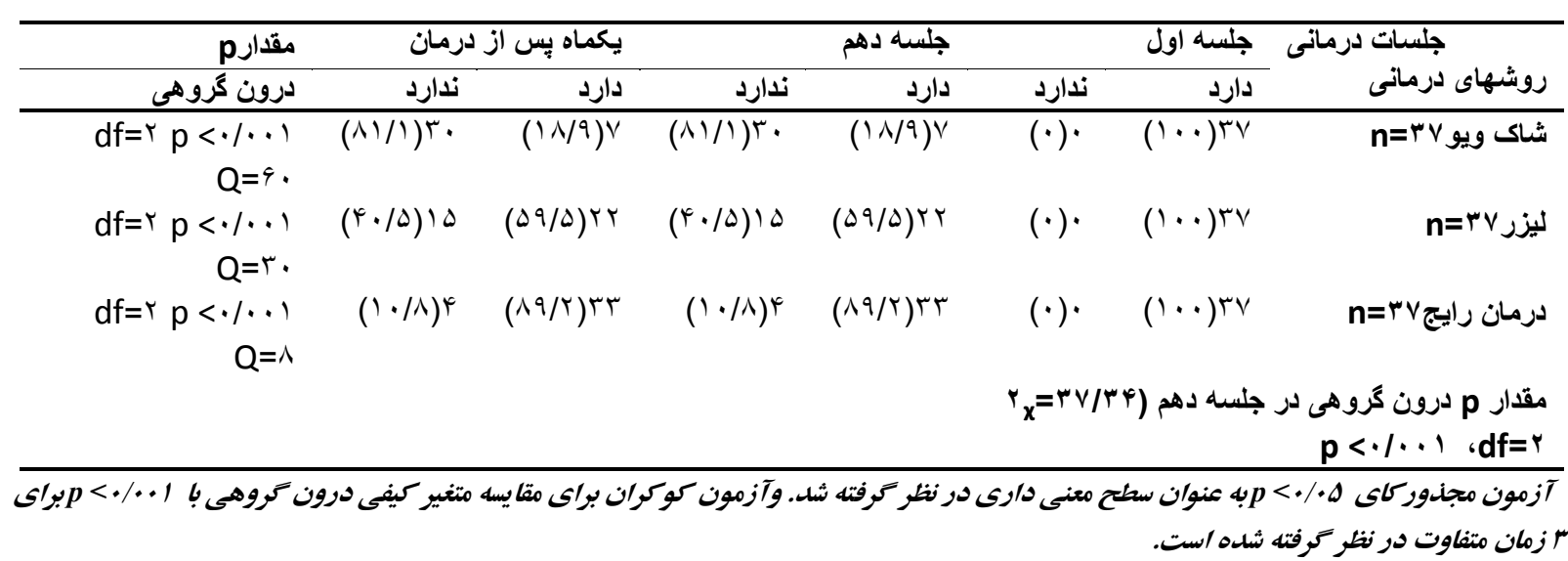




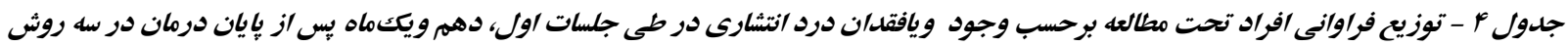

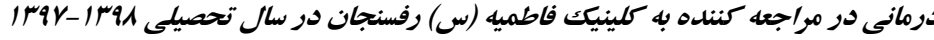

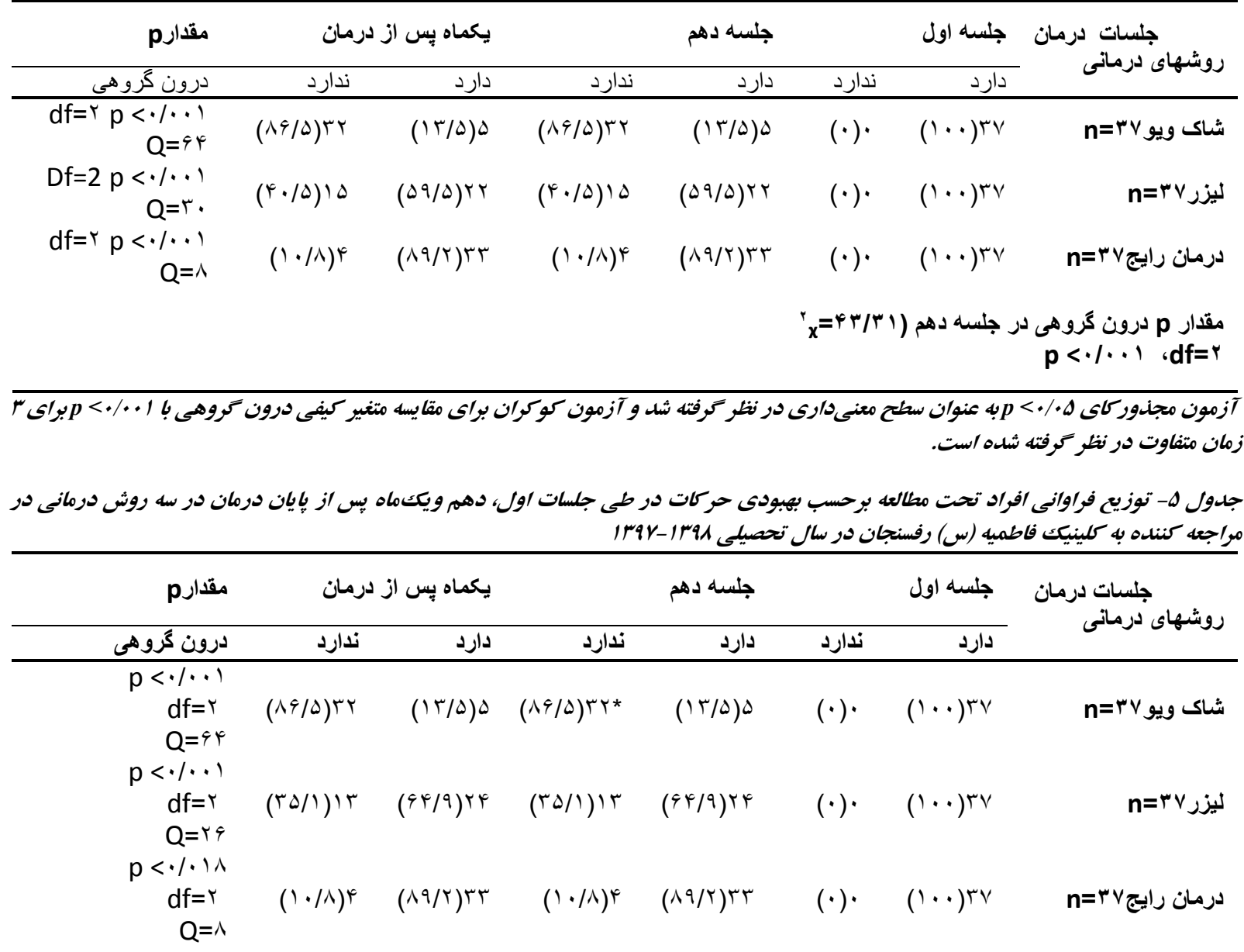

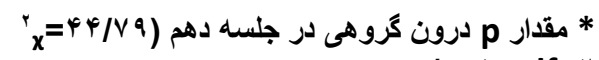

$p<\cdot 1+$, $d \mathbf{d f}=r$

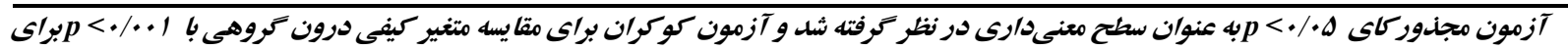

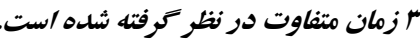

از نتايج اين مطالعه مىتوان استنباط كرد كه شاك ويو طى

• 1 جلسه درمان در كاهش شدت درد موضعى نقاط ماشهاى

ميوفاسيال مؤثرتر از روشهاى ليرز كم توان و درمان رايج بوده است. اين نتيجه شايد به دليل ساز و كار اثرات شاك ويو باشد كه سبب ترميه، بازسازى بافتهاى عضلانى، غير فعال شدن و از بين يردن باند سفت عضلانى باشد. جون اگر باند سفت

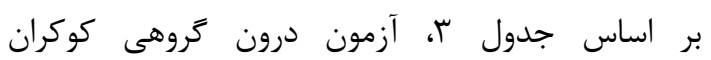
نيز نشان داد كه هر سه روش درمانى در برطرف (Cochran) كردن باند سفت عضلاتى، كاهش درد انتشارى، بهبودى حر كات در طى جلسات درمانى مؤثر بودهاند اگر جه شاك ويو از ليزر و ليزر از درمان رايج اثر بهترى نشان داده است.

بحث 
N م N مقايسه تأثير شاك ويو درمانى و ليزر كم توان در درمان نقاط ماشهاى ميوفاسيال ...

ازدرمان رايج بوده است. اين يافته با مطالعات بسيارى از محققان همخوانى داشت [rr-r I I ] و با مطالعه Cardaso و همكاران مطابقت نداشت [19]. بين كاهش درد انتشارى و روشهاى درمان ارتباط معنى دارى وجود داشت به طورى كه شاك ويو له/1 درصد موارد مؤثرتر ازروش ليزر و درمان رايج بوده است. اين يافته با مطالعات عدهاى از محققين مطابقت داشت [YF-9]. ولى مطالعه Ibrahim اين نتيجه را تأييد نمى كند [با]]. همجنين ليزر در |ه/• درصد موارد براى كاهش درد انتشارى مؤثرتر از درمان رايج بود. اين يافته با مطالعات تعدادى از يزوهش كران همخوانى داشت [بr-r I I و با مطالعه Cardaso و همكاران مطابقت نداشت [19]. دليل اين مغايرت بخاطر اين است كه عضلات مختلفى در اين مطالعه مرورى استفاده شده بود يافتههاى اين مطالعه نشان مىدهد شاك ويو در ه/ 1/ درصد موارد براى بهبودى حركات كردن از روشهاى ليزر ودرمان رايج مؤثرتر بوده است. اين يافته با نتايج تحقيقات محققين ديگر مطابقت داشت [N-Tه]. ولى با مطالعه Ibrahim همخوانى نداشت [1/]]. هم:جنين ليزر در //هـادرصد موارد براى بهبودى حركات مؤثرتر از درمان رايج بود. اين نتيجه با مطالعات عدهاى از محققان همخوانى داشت [r Cardaso و همكاران مطابقات نداشت [19]. به طور كلى، استفاده ازشاك ويو و ليزر در درمان نقاط ماشهاى ميوفاسيال عضله ذوزنقهاى مؤثرتر از درمانهاى رايج فيزيوترايى مىباشد. همرجنين اين دو روش از ساير درمانها
عضلانى از طريق ضربات شاك ويو از بين برود سبب كاهش درد موضعى، درد انتشارى و بهبود حر كات مىشود. مطالعه بسيارى از محققان اين يافته را تأييد مى كنند كه آنها هم اثر شاى ويو را مؤثرتر از ساير درمانها (ليزر و اولتراسوند) در

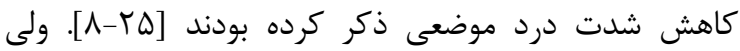
تحقيق Ibrahim و همكاران با اين نتيجه مغايرت داشت [1 II]. اين مغايرت شايد به دليل نداشتن كروه ليزر درمانى آن تحقيق باشد، همرجنين ليزر در طى • ا جلسه درمان در كاهش شدت درد موضعى نقاط ماشهاى از درمان رايج مؤثرتر بوده است. اين نتيجه شايد به دليل افزايش خون رسانى عضلات باشد كه عملكرد سلول را تغيير مىدهد و سبب طبيعى شدن كار سلولها از طريق توليد آدنوزين ترى فسفات در سلولها شود و آنها را ترميم مىنمايد و به اين دليل سبب كاهش درد

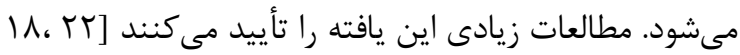
Cardoso و همكاران همخوانى IIT، IV، ولى با مطالعه نداشت [9 19]. دليل اين مغايرت شايد به علت استفاده ليزرهاى با شدت و توان متفاوت و عضلات مختلف در اين مطالعه

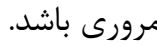
نتايج اين مطالعه نشان مىدهد كه شاك ويو در 11/1 درصد موارد براى از بين بردن باند سفت عضلانى كه شامل تداوم درد نقاط ماشهاى ميوفاسيال مىباشد، مؤثرتر از دو روش ديكر بوده است. اين يافته با تحقيقات بسيارى از

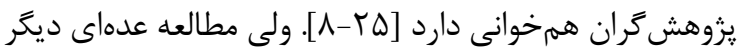
اين نتيجه را تأييد نمى كند ["اl]. همرجنين ليزر در ه9/Dه درصد موارد براى از بين بردن باند سفت عضلانى مؤثرتر 


\section{نتيجهل}

از يافتههاى اين مطالعه مىتوان نتيجه كرفت كه كاربرد

شاك ويو در طى •1 جلسه مىتواند در كاهش شدت درد

موضعى، از بين بردن باند سفت عضلانى، بهبودى حركات

كردن وكاهش درد انتشارى نقاط ماشهاى ميوفاسيال عضلات

ذوزنقهاى مؤثر باشد به اين دليل توصيه مى

ويو در درمان نقاط ماشهاى ميوفاسيال عضلات ذوزنقهاى

$$
\text { استفاده مىشود. }
$$

$$
\text { تشكر و قدردانى }
$$

از اعضاى شوراى يزوهشى دانشكاه علوم يزشكى رفسنجان، واحد

توسعه تحقيقات بالينى بيمارستان على ابن ابى طالب (ع) به دليل تصويب اين طرح تحقيقاتى، از معاونت يزوهشى دانشحاه به جهت حمايت مالى از طرح و همجنين از بيمارانى كه در اين مطالعه شركت نمودهاند تقدير و تشكر به عمل مىآيد.
نظير مصرف دارو و تزريق داخل عضلانى بهتر است جون مصرف داروها عوارض گَوارشى دارند و تزريق داخل عضلانى به خصوص استفاده از تركيبات استروئيدى عوارض زيادى نظير درد شديد، عفونت و ترس بيمار دارد، ولى استفاده از شاك ويو و ليزر جنين عوارضى ندارند و علاوه بر اين ارزان و بىخطرند [19]. اين مطالعه شامل محدوديتهاى نيز بود. اولين مورد ها نفر از بيماران به دليل نامعلوم در ابتداى تحقيق شركت نكردند و مطالعه را ترك كردند كه در اين حالت براى جايگزينى آنان مجددا بيمار يذيرش شد. دومين محدوديت در مطالعه اين بود كه اخر روشهاى مورد بررسى به طور تر كيبى استفاده مىشدند، احتمالاً نتايج بهترى در برداشت. بنابراين براى مطالعات آينده در اين زمينه ييشنهاد مى براى درمان بيماران مبتلا به نقاط ماشهاى ميوفاسيال استقاده

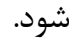

\section{References}

[1]. Ferguson LW, Gervin R, Clinical mastery in the treatment of myofascial pain, $1^{\text {st }}$ ed, Philadelphia, Willams and Wilkins. 2005; PP: 92-150.

[2]. Chaitow L, Fritz S, A massage therapist's guide to understanding, Locating and treating myofascial trigger point. $1^{\text {st }}$ ed, Philadelphia, Churchil Living Stone. 2006; PP: 1-56and 60-68.

[3]- Gleitz M, Horning K, Trigger point-diagnosis and treatment concepts with special reference to extracorporeal shockwaves, Orthopade 2012; 41(18): 113-25. 
• به مقايسه تأثير شاكى ويو درمانى و ليزر كم توان در درمان نقاط ماشهاى ميوفاسيال ...

[4]- Sharkey J, The Concise Book of Dry Needling: A Practitioner's Guide to Myofascial Trigger Point Applications. $1^{\text {st }}$ ed, England, Lotus Chichester. 2017; PP: 112-16.

[5]- Taheri P, Vahdatpour P, Andalib S. Comparative study shockwave therapy and laser therapy effect in elimination of symptoms among Patients with myofascial pain syndrome in upper trapezius, $A d v$ Biomed Res 2016; 5(138): doi: 10.4103/22779175.187398.

[6]- Donatelli RA. Physical Therapy of the Shoulder. $2^{\text {nd }}$ ed, New York, Churchil Livingstone. 2011; PP: 319-29.

[7]- Mushtaq S, Pattnaik M, Mohanty P. Comparison of two treatment techniques: shockwave therapy and ischemic compression in subjects with upper trapezius myofascial trigger points, International Journal of Develoment Research (IJDR). 2017; 7(10): 15753-60.

[8]- Ji HM, Kim HJ, Han SJ. Extracorporeal shockwave therapy in myofascial pain syndorme of upper trapezius, Ann Rehabil Med 2012; 36(5): $675-80$
[9]- Gur A, Koca I, Karagullu H, Altindag O, Madenci E. Comparison of the efficacy of ultrasound and extracorporeal shockwave therapies in patients with myofascial pain syndrome: A randomaized controlled study, Journal of Musculoskeletal Pain 2013; 21(3): 210-16.

[10] Jeon JH, Jung YJ, Lee JY, Choi JS, Mun JH, Park WY and etal. The effect of extracorporeal shockwave therapy on myofascial pain syndrome, Ann Rehabil Med 2012; 35(5): 665-74.

[11]- Watson T. Electrotherapy (Evidence-Based Practice). 12th ed,Edinburg,Chirchil Livingstone, 2008; PP: 161-77.

[12]- Shahimoridi D, Eghbali M, Vaziri Nejad R, Najafzadeh N. Using Low Power Laser in the treatment of the myofascial trigger point, $J$ Rafsanjan Univ Med Sci 2009; 8(2): 99-107.

[13]-Ibrahim DSM, Amin DI, Abdel Raoof NAL, Shockwave therapy versus progressive pressure release on myofascial trigger points, International of Therapies and Rehabilitation Research 2017; 6(5): 5-14. 
[14]- Suputtitada A, Update of extracorporeal shockwave therapy in myofascial pain syndrome, Int Phys Rehab 2017; 1(4): 82-6.

[15]- Akturk A, Kaya A, Cetintas D, Akgol G, Gulkesen A. Comparision of the effectiveness of ESWT and ultrassound treatment in myofascial pain syndrome:randomized sham-controlled study, J Phys Ther Sci 2018; 30: 448-53.

[16] Lowe JD. The effectiveness of Chiropractice manipulation and ischemic compression versus chiropractic manipulation and shockwave therapy on trapezius trigger points, Creative Commons. 2018;http:/hdl.handel.net/10210/268972.

[17]- kannan P, Management of myofascial pain of upper trapezius: A three group comparison study, Global Journal of Health Science 2012; 4(5): 4652.

[18]- Gurudut P, Bhadauria E, Comparetive effectiveness of low level laser therapy, ultrasound therapy and compined effect of both on trigger points. Int J Physiother Res 2016; 4(5): 1701-6.

[19]- Cardoso LM, Kraychete DC, Araujo RP. Effectiveness of Laser therapy in the treatment of myofascial pain, American International Journal of Cotemporay Research 2016;6(4):46-52.

[20]- Shahimoridi D, Nikian Y, Abadian SH, Rahighi S, Shariati M. Comparison of ultrasound and muscle stretch with ultrasound and muscle stretch alone in the treatment of myofascial trigger points, Journal of Kerman University of Medical Sciences 1996; 3(4): 160-7 [Farsi].

[21]- Taheri N, Aqarezai M, Serami H. Shochwave Therapy (Concepts, Indications, Effective Parameters), $1^{\text {st }}$ ed, Isfahan, Yakta. 2017; PP: 53162.

[22]- Yang YJ, Lee Sj, Choi M. Preasure pain threshold and visual analogue scale changes in the high and low energy extracorporeal shochwave, Physical Therapy Rehabilitation Science 2014; 3(2): 142-7.

[23] Taheri P, Vahdatpour B, Andlid S, Baraderan Mahdavi S, The effect of low level laser therapy, excercise therapy and medication on myofascial pain syndrome of upper trapezius: A clinical trial study, J Rafsan Univ Med Sci 2019; 18(4): 365-75

[24]. Kiraly M, Bender T, Hodosi K, Comparative study of shockwave therapy and low level laser 
T T مقايسه تأثير شاكى ويو درمانى و ليزر كم توان در درمان نقاط ماشهاى ميوفاسيال ...

therapy effects in patients with myofascial pain

syndrome of the trapezius, Rheumatology

International 2018; 38: 2045-52.

[25]. Khalil SS, Abdulla MM. The effect of extracoporeal shocwave therapy versus ultrasound therapy in patients with myofacial pain syndrome in trapezius muscle, Physical Medicine and Rehabilitation 2018; 2(1): 101-8.
[26]. Park KD, Lee Wy, Park M, Ahn Jk, Park Y. High versus low energy extracorporeal shockwave therapy on myofascial pain syndrome of upper trapezius, A prospective randomized single blinded pilot study, Medicine 2018; 97(28): e11432. 


\title{
Comparing the Effect of Shockwave Therapy and Low Level Laser on Treatment of the Myofascial Trigger Points of Trapezius Muscles: A Randomized Clinical Trial
}

\author{
D. Shahimoridi $^{1}$, M. Mollahossini ${ }^{2}$, H. Azin ${ }^{3}$, H. Ahmadinia ${ }^{4}$
}

Received: 30/606/2020 Sent for Revision: 27/07/2020 Received Revised Manuscript: 27/09/2020 Accepted: 19/10/2020

Background and Objectives: Muscles are known as organs which can generate pain in human body. Among different types of muscle pain, myofascial trigger points (MTPs) are very common. The aim of this study was comparing the effect of shockwave therapy (SWT) and low level laser therapy (LLLT) on the treatment of the MTPs of trapezius muscles.

Materials and Methods: This randomized clinical trial was performed in Fatemieh physiotherapy clinic of Rafsanjan, Iran, in 2019. One hundred and eleven patients conflicted to MTPs of trapezius muscles were randomly assigned into three equal groups of 37 . Treatment methods were included SWT, LLLT and conventional physiotherapy (CP) during 10 sessions. Intensity of local pain, tense band of the muscle, radicular pain and limitation of movements were assessed in $1^{\text {st }}, 10^{\text {th }}$ and 10 days after treatment. Data was analyzed using two-way repeated measures ANOVA followed by Tukey's post hoc test and chi-square test.

Results: The findings of this study showed that SWT during 10 sessions was more effective than LLLT and CT in relief of intensity of local pain of the MTPs $(p<0.001)$. Also, in the $10^{\text {th }}$ session, chi-square test showed that SWT in comparison with LLLT and CT can be more effective in removing tense band of the muscle, improving movements and reducing radicular pain $(\mathrm{p}<0.001)$.

Conclusion: According to this study, during 10 sessions, SWT can be effective in the relief of local pain of MTPs, radicular pain, improving movements and removing muscle tense band.

Key words: Shockwave therapy, Low level laser, Myofascial trigger points, Trapezius muscles

Funding: This study was funded by Rafsanjan University of Medical Sciences.

Conflicted interest: None declared.

Ethical approval: The Ethics Committee of Rafsanjan University of Medical Sciences approved the study (IR.RUMS, REC.1397.239).

How to cite this article: Shahimoridi D, Mollahossini M, Azin H, Ahmadinia H. Comparing the Effect of Shockwave Therapy and Low Level Laser on Treatment of the Myofascial Trigger Points of Trapezius Muscles: A Randomized Clinical Trial. J Rafsanjan Univ Med Sci 2020; 19 (8): 819-32. [Farsi]

1- Instructor, Dept. of Basic Sciences, Faculty of Medicine, Rafsanjan University of Medical Sciences, Rafsanjan, Iran, ORCID: 0000-00023915-5726

(Corresponding Author) Tel: (034) 34280000, Fax: (034) 34280097, E-mail: d.shahimoridi@gmail.com

2- Associated Prof., Dept. of Orthopedics, Faculty of Medicine, Rafsanjan University of Medical Sciences, Rafsanjan, Iran, ORCID: 0000-00034116-2527

3- Instructor, Dept. of Neurology, Faculty of Medicine, Rafsanjan University of Medical Sciences, Rafsanjan, Iran, ORCID: 0000-0001-81793898

4 PhD Student of Biostatistics, Dept. of Epidemiology and Biostatistics, Faculty of Medicine, Rafsanjan University of Medical Sciences, Rafsanjan, Iran, ORCID: 0000-0002-7010-1726 